\title{
A Feasibility Study to Inaugurate the Rangsit Crime Survey
}

\author{
Jomdet Trimek ${ }^{1}$ \\ ${ }^{1}$ Criminology and Criminal Justice Adminsitration, Rangsit University, Pathumtani, Thailand \\ Correspondence: Jomdet Trimek, Criminology and Criminal Justice Adminsitration, Rangsit University, \\ Pathumtani, Thailand. Tel: 66-8-6989-4460. E-mail: jomdet@rsu.ac.th
}

Received: August 10, 2014 Accepted: November 6, 2014 Online Published: February 12, 2015

doi:10.5539/ass.v11n5p48 URL: http://dx.doi.org/10.5539/ass.v11n5p48

\begin{abstract}
Thailand's crime data collection system is yet to be on par with international standards, resulting in distorted analysis of actual crime situation and difficulty in formulating crime reduction policy. This research analyses crime data collection system of the United States and the United Kingdom in order to study ways to inaugurate a crime survey and find out the best means of carrying out such project by Rangsit University. This research is conducted qualitatively via in-depth interview of six crime data collection and analysis experts in order to recognise the problems and formulate solutions for crime data collection in Thailand. In addition, a focus group consisting of eight crime data collection experts will be formed to determine the procedure involved in the Rangsit Crime Survey. The researchers found out that crime data collection system in Thailand, in particular the Royal Thai Police's five-group crime data collection, still has shortcomings in terms of redundant and outdated offense categorisation, and problems in data collection and dissemination. Crime survey conducted by the Office of Justice Affairs still has limitations regarding the development of interview forms, data collection, budget constraints, and dissemination of data which may be harmful to other state agencies. As for the feasibility of conducting crime survey by Rangsit University, the experts agree that such survey be conducted in the form of Crime Fear Poll, the most feasible method which incurs least costs and minimal staff requirements. The name of the project will be the "RSU Crime Survey".
\end{abstract}

Keywords: crime survey, crime data collection system, crime, victim

\section{Introduction}

The crime problem or the safety problem of the citizen's life and property is one of the important problems for evaluating the quality of life of the citizens in the society because the existing of the crime can cause the negative impacts to the citizen directly and indirectly as well as can be a factor to stop the growth and country development. To protect the crime problem most efficiently, it needs to have the policy and strategy for this problem solving clearly and directly to the problem point. The most important of the main data to analyze for planning to prevent the crime problem is the crime statistics. Thus, if there is the imperfection or the flaw in the crime statistics even the data collection or the statistic number of criminal cases which are not consistent with the truth, it may directly impact to lower the efficiency of the tools to prevent the crime as well. This research analyzes the pattern from The British Crime Survey or The Crime Survey for England and Wales, The US Uniform Crime Report (UCR), and National Crime Victimization Survey (NCVS) to be a prototype by studying from the beginning to build the pattern of crime statistic collecting from the crime victims to the method of the implementation including the problems and obstacles occurred in order to utilize the way of data analyzing and the development of the data collecting system in Thailand. Moreover, the researcher will study the direct and indirect related statistical methods of the crime problem in the related organizations and institutions in Thailand for analyzing the benefits, methods, processes, and the possibility to create the survey project of the crime status with the Rangsit Crime Survey. This includes the study of the possibility of using the crime statistics to be the main statistics following with the 5 groups of the crime case statistics of the Royal Thai Police at the present time. This is for better reflecting the scope of the crime happening including for creating the policy to solve the crime problem, and for the providing the budget using for the crime problem in each area to be right to the problem and more efficient than the present time.

\subsection{Objectives}

1. To study the way of the crime statistic survey and the problems and obstacles for the crime survey in the United Kingdom and the United States 
2. To study the way of the crime statistic survey and the problems and obstacles for the crime survey in Thailand

3. To study the possibility and the direction of the survey project of the crime status by the Rangsit Unverisity

\section{Method}

To study and pattern of the British Crime Survey or The Crime Survey for England and Wales and the Uniform Crime Reports (UCR) and to survey the National Crime Victimization Survey (NCVS) of the United States by studying from the beginning to build the pattern of crime statistic collecting from the crime victims to the method of the implementation.

Also, this work will analyze the way of the statistical crime survey with the problems and obstacles occurred in order to utilize the way of data analyzing and the development of the data collecting system in Thailand through the qualitative research with the In-depth interview from the 6 key informants showing in the table 1 as follows.

Table 1. List of the key informants

\begin{tabular}{lll}
\hline Name & Position \\
\hline 1 Rear Admiral Dr.Virog Pimanmadsuriya & $\begin{array}{l}\text { The Director of the Social Innovation Research Center, } \\
\text { The founder of Rangsit Poll } \\
\text { Chief of Police of the Central Information Technology } \\
\text { Center, Office of Information Technology and } \\
\text { Communication, the Royal Thai Police } \\
\text { The Spokesperson of the Metropolitan Police Bureau }\end{array}$ \\
3 & Police Colonel Dr. Narongsak Bavornvongpitak & $\begin{array}{l}\text { Chief of the Justice Information Development Center, } \\
\text { Office of Justice Affairs, Ministry of Justice } \\
\text { Political Science Chulalongkorn University; the } \\
\text { Beginner of Making the Crime Statistic Survey Report } \\
\text { Assistant Director of the ABAC Poll }\end{array}$ \\
\hline
\end{tabular}

And study the possibility and direction of the survey project of the crime status by the Rangsit University through the Focus Group of the experts in the statistical survey on the crime problem from several related units such as the experts from the office of justice affairs, national statistic organization, ABAC Pole, and institute for the population and social research, Mahidol University. All the experts are not intending to reveal the organization name due to the regulation of the information providers.

\section{Results}

\subsection{Data Collecting and the Crime Statistic in the United Kingdom}

England and Wales started to collect the crime statistic by the Home office. At the first time, the data were collected only from the cases which are in the court consideration or the cases that already get the judgment. Until 1857, the case statistics from the police report were applied and there has been the development of the statistic collecting annually, 3 important reports were the National Crime Survey of England and Wales, punishment statistics of the court of justice, and the statistics of the prisoners from the department of correction. In 1982, the home office of the Great Britain brought the victimization survey at the first time which was called The British Crime Survey (BCS); (Smith, 2006). At present, the national crime survey of England and Wales has 2 main statistic crime collecting which are:

Police Recorded Crime is to collect the data from the police officers in each area that received the report and recorded the data. However, this method does not include the cases that are not report to the police or not record yet. (The report are obtained from 44 police stations and the police working in the public transportation (Office of National Statistics, 2012))

The British Crime Survey or now is called the Crime Survey for England and Wales which is moved from the Home Office to the Office for National Statistics (Office of National Statistics, 2012). This is the survey by sampling the candidates from the citizens living in different areas all over the country by not having age, gender, or nationality factors. The survey is for the numbers of the crime or anti-social behaviors that the victims did not report to the police, the feeling of the citizens and society to the crime, or the satisfaction of the job of the police or justice process, etc. The survey utilizes the face to face interviews, in the past, the survey is selected the persons 16 years older, but since 2009, the survey add the groups of the children and teenagers during $10-15$ years (BMRB, 2009) 
In each way of the crime statistic collecting methods, either the crime statistics obtained from the police or from the crime survey of the citizen, both have different advantages and disadvantages. So, the combination of both methods by analyzing the collected data carefully and distributes of the advantages and disadvantages of the data collecting system will be able to demonstrate the crime status happened in society more than using either one method. Therefore, each year the Home Office of England publishes the academic report from both sources: Crime in England and Wales: Finding form the British Crime Survey and Police Recorded Crime by notifying the survey result of each category for each crime type, places, time, citizen attitude to the crime, and the data comparison showing the overall crime in the country including the response of the crime trend in the past and going-to-be in the future (Home Office, 2011). The national crime statistics of England and Wales categorize into 11 groups of crimes (152 guilty) as follows

1. Violence (injured)

2. Violence (not injured)

3. Sexual Offense

4. Robbery

5. Domestic Burglary in the dwelling

6. Vehicle Offense

7. Other Theft

8. Fraud Offense

9. Criminal Damages

10. Drug Offense

11. Other Crimes

3.2 The Problem and Obstacles of the Crime Statistics in the United Kingdom

Although the classifications of the crime statistics by the national police department in England and Wales are the most elaborated in the world (Newburn, 2007), there are still the problems such as:

1. The overlap of the data collecting by the national police department and the citizen's crime survey.

2. From the survey, the published national crime statistics are too complicated and difficult to understand for the people who do not study the crime statistic directly, and cannot connect the data for the people understanding.

3. The change of the responsible units from the Home Office to the National Statistics in England makes the working gap. So, the statisticians of the Home Office should cooperate with the statisticians of the national statistics for national crime statistic report annually.

4. The citizen crime statistic survey does not pay attention much on the crime case occurred to the children of 10 - 15 years.

5. The counting rules of the crime statistic often changes causing the uncertainty of the crime statistic comparison for each year

6. The national crime survey does not collect some data such as the statistics of the punishment, prisoners, etc. and not include the crime mapping

7. The publication of the national crime statistics is not enough efficient.

\subsection{The Data Collecting and the Crime Statistics in the United States}

\subsubsection{The Uniform Crime Report (UCR)}

The Uniform Crime Report in the United States began from the cooperation between the International Association of Chiefs of Police (IACP) and the Social Science Research Council (SSRC) in 1920 and defined the pattern and types of basic crime to 7 types which are:

1. Murder (intention)

2. Murder (no intention)

3. Rape

4. Trespassing 


\section{Body injury}

6. Theft

7. Vehicle Robbery

During the beginning period, the Federal Bureau Investigation (FBI) came to help the monthly report making that first published on January 1930 by collecting the data from 400 cities in 43 states covering more than 20 million people or $20 \%$ of the US population at that time. Then, the law to protect the data collecting was implemented and there were the designation of the officers directly response for the national crime statistics which are the FBI officers. At present, the UCR consists of 17,000 data collecting units covering $93 \%$ of the US population in 46 states. The UCR classifies the crime type by the guilty to 2 main groups: Index Crime part 1 and Index Crime part 2. Index Crime part 1, violence crime consists of 8 types and Index Crime part 2, non violence crime consists of 21 types which are shown in the Figure 1:

Index Crime part 1

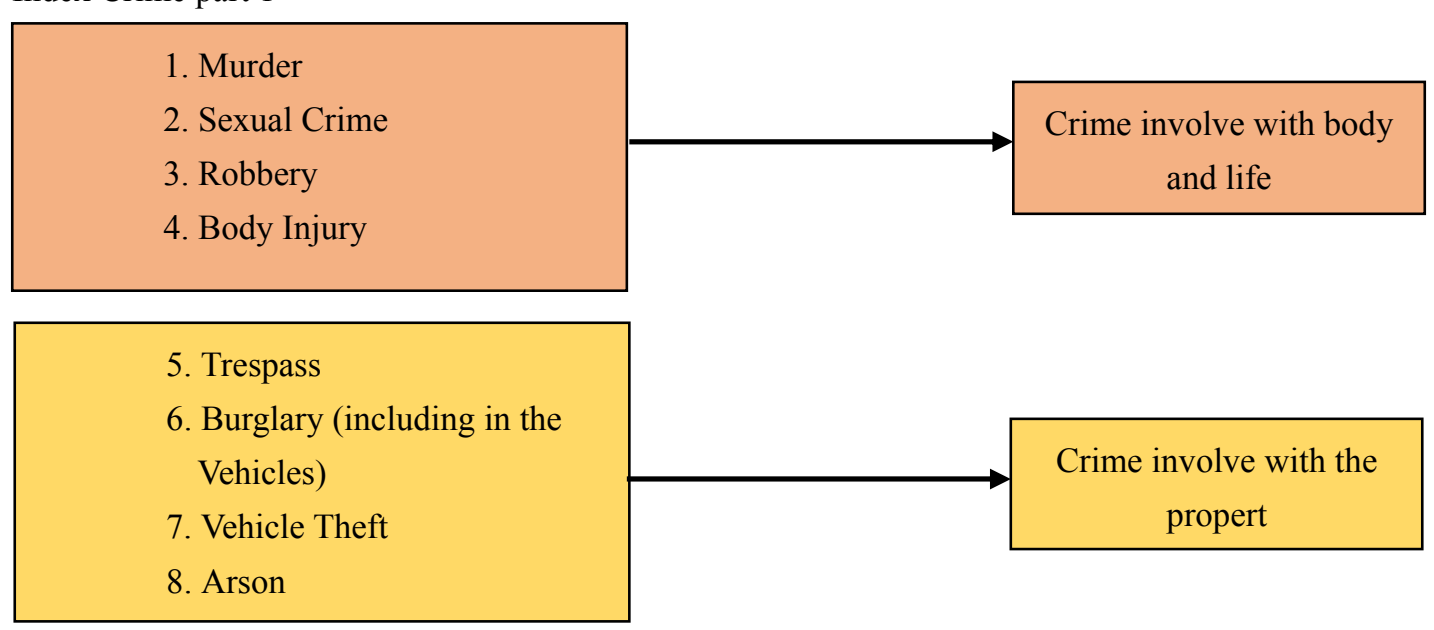

Figure 1a. (Part 1: Index Crimes)

Source: Department of Justice (2004)

Index Crime part 2

1. Domestic Violence
2. Drunk Driving
3. Crime about the alcohol law
4. Drunken Rampage
5. Abnormal Behavior
6. Be the homeless
7. Other Crimes
8. Be a suspect
9. Violate the law or trespass
10. Escape the arrest or control

\begin{tabular}{l} 
11. Body Injury (not serious) \\
12. Deception \\
13. Fraud \\
14. Misappropriate \\
15. Robbery (property, goods) \\
16. Criminal Damage \\
17. Weapon holding \\
18. Prostitute \\
19. Sexual Offense \\
20. Drug Using \\
21. Gambling \\
\hline
\end{tabular}

Figure $1 \mathrm{~b}$. The UCR classifies the crime type

Source: Department of Justice (2004)

The data collecting by the related units of the law enforcement in the local level cooperates to report from the victims and if the investigation in that case cannot go further or implement, it will be cut out of the system. So, the data of the actual offense known will be reported. The UCR employs 3 methods to demonstrate the crime 
data. The first one is the number of the criminal reported to the police and capture will report not in detail such as the killed victims in 2005 equal ...... people, and the second one will present the rate of change in each crime case in the percentage to show the trend of crime, increase or decrease, and the last method presents the rate of crime by calculating from one hundred thousand population: The formula is

$\frac{\text { Number of Criminal }}{\text { Total Population }} \quad \mathrm{x} 100,000=$ the rate of Crime

Figure 2. The formula to calculate the rate of crime Source: Department of Justice (2004)

\subsubsection{National Crime Victimization Survey: NCVS}

The national crime victimization survey in the United States started the survey in 1973 because the crime statistics used at that time could not measure the actual crime number and there were a lot of crime victim who are not reported to the police. Therefore, the government started the survey by supporting the budget and allowing the National Crime Victimization Survey (NCVS) to be the response units to create more accurate and trustful crime statistic in the US. The citizen survey does not involve only the number of crime, but also collect the data of person or groups of people that have the high risk to be the crime victim, areas, and high risk time, etc. The survey is implemented annually by phone interviewing and using the questionnaires to be main tools to collect the data and classify the crime types clearly from 12 big cities which are Chicago, Kansas City, Knoxville, Los Angeles, Madison, New York, San Diego, Savanah, Spokane, Springfield, Tucson, and Washington DC by the Department of Justice. The interviewee have the age 12 years and older by not defining the gender from the dwellers and collect the data of age, gender, nationality, marriage status, income, education level, the relationship between the victims and criminals, place and time of the crime incidents, the weapons using level, and the crime damage. In 2012, the survey covered 92,390 households with 162,640 people (Bureau of Justice Statistics, 2012). The crime statistics are collected as follows:

1. Violence Crime

1.1 Rape/Sexual Assault

1.2 Robbery

1.3 Assault

1.3.1 Aggravated assault

1.3.2 Simple assault

1.4 Intimate partner violence

1.5 Violent crime involving injury

2. Serious violent crime

2.1 Domestic Violence

2.2 Serious Crime using weapons

2.3 Serious Crime with injury

3. Crime about the asset

3.1 Robbery in the dwelling

3.2 Vehicle Theft

3.3 Pickpocket

3.4 The Problem and Obstacles of the Crime Statistics in the US

The limitation of UCR data collecting

1. Federal Crime is not reported

2. The reported information is the voluntary of each organization. So, the accuracy and perfect of the information is missing

3. Not all units/Police station reported 
4. The FBI evaluation of crime is still estimation

5. There is the overlap of crime types that are there are the reports only the most severe crime such as the criminal who makes the multiple crimes in the same incidents even rape, robbery, and murder, etc.

6. There is the combination of crime into the same crime

7. The meanings for the scope of crime are different in each state

The Limitation of the National Crime Victimization Survey

1. The incident reports are not exact or more than the truth because of the misunderstanding of the crime behavior. For example, the missing purse will report as the robbery or forgetful-open front door will report to the housing burglary, etc.

2. No crime report due to the embarrassment of the crime victims; for example; forgetting the asset or the sexual offense crime

3. Unable to record all of the personal data such as the person using drug or the gambling, etc.

4. Random sampling cannot be the proxy of the overall population

5. The inappropriate pattern of the questions that are complicated and too much may cause the respondents not understand and cannot communicate clearly

6. The data collecting of the crime statistics does not collect the data of the person under 12 years old including the juvenile who are the high level crime victim such as the sexual crime.

\subsection{The Way of the Crime Statistic Collecting and Its Problems for the Organization in Thailand}

\subsubsection{Groups of Statistic Crime of the Royal Thai Police}

It is the system of the crime statistic collecting form the incident report of the citizens who are the crime victim or there are the criminal arrests by the police patrol. Then, the investigator will send the report to the high ranking offices such as the Police Division or the Police Bureau that the station is under to bring the data and summarize and conclude to be the overall picture of the all crime in the country for monthly and yearly. The responsible unit for collecting the central data is "the center of the central information technology" which is the Bureau Ranking organization under the control of the Bureau of the information and technology, The Royal Thai Police. The data recording classifies the crime into 5 types as follows:

Group 1: Violence and Dreadful Crime such as

\subsection{Murder by intention}

\subsection{Robbery}

1.3 Property Offense (the victim injured and not injured)

\subsection{Kidnapping}

1.5 Arson

Group 2: Crime to the Victim Life, Body, and Sex such as

\subsection{Murder by intention}

2.2 Murder by not intention

2.3 Negligence offense causing other people dead

\subsection{Attempt to kill}

2.5 Body injury

2.6 Rape

Group 3: Crime involving with the asset or property offense such as

\subsection{Burglary}

\subsection{Snatch and run}

3.3 Blackmail

\subsection{Extortion}

3.5 Robbery 


\subsection{Robbery}

3.7 Buying the robbery items

3.8 Property losing

Group 4: Interest Crime Case

4.1 Motorcycle Theft

4.2 Automobile Theft

4.3 Cattle Theft

4.4 Agricultural Equipment Theft

4.5 Bus Robbery

4.6 Taxi Robbery

4.7 Rape and kill

4.8 Kidnapping

4.9 Cheating Fraud

4.10 Criminal Misappropriation

4.11 Crime involving Tourists

Group 5: Crime that the government is the victim

5.1 The Firearms Act (normal gun, war gun, grenade)

5.2 The Gambling Act (general gambling, lottery)

\subsection{The Drug Act}

5.4 The Prostitute Prevention Act

5.5 The Entertainment Place Act

5.6 The Hotel Act

5.7 The publication or having the pornography items

\subsubsection{The Problem of the Crime Statistic Collecting for the 5 Groups of Crime of the Royal Thai Police}

After interviewing the police officers who have the responsibility of data collecting and processing of 5 groups of crime, we found that the crimes of 5 groups have some flaws of the classification that has the overlap among the crime type in case of the robbery, theft, vehicle theft. This can cause the statistical error from the actual crime. Also, there is no record classification for the dwelling robbery and public robbery leading to unable to define the policy separately. Moreover, another crucial problem is that the crime recording counts only the crime case recording by the investigators that not include the other crime incidents occurred but not notify or report to the police or even notify the police, but not record in the police book. This information is called the Dark Figure Crime that makes the obtained statistical data deviates from the actual incidents. The mentioned problem may be caused by the unsuitability of the investigator discretion and leads to several actual crimes are not in the crime statistic analysis correctly. This affects to the crime protection planning which has the important from the crime statistics to be inefficient and has the obvious error. In addition, there are the problems of the technology experts, error recording, and the publication that does not reach the international standard. In summary, the formal crime statistic collecting from the police recorded crime of the Royal Thai Police still lacks of the collecting standard and need to improve the working process of the data collecting urgently.

\subsubsection{Crime Victimization Survey}

The report making of the crime victimization survey in Thailand firstly established by "center for justice statistic, the office of justice affairs" annually. The first report was published in 2005 that is the pilot project survey in Bangkok. Then, in 2006, another pilot crime survey was in Nakorn Srithammarat to be a proxy of the suburb area. In 2008, the first national crime survey was established and published in 2009 using 2 million baht budget. The center for justice statistic provides the way of data collecting that the correct method is sending the questionnaire or tools to the national statistic organization (NSO) officers. Since the NSO officers have the normal duty to make the population census, when the center for justice statistic uses this method, it can collect the sampling nationwide within 2 million Baht budget. The NSO officers will ask the questions in the questionnaire of the crime victimization survey adding from the population census questions. This questionnaires 
as a tool of interview are applied from the National Crime Victimization Survey Questionnaire of the US. The center of justice statistic develop by translating and having the academic group leading by Professor Jutharat UeAmnuay who is the person driving this first survey. The questions as a tool using by the NSO consists of 2 forms (Appendix 2) that the officers will interview following by the questions of the first form as "Over the past year, Did you use to have the crime experience or not" If yes, the questions of the second form will be asked which is the question about the detail of crime, but the question in the questionnaires are too complex for the normal people to answer by themselves. Thus, it is necessary to have the NSO officers interview following the pattern and record from the interview again. The sampling method and the household classification, the NSO officers will not open the information because of the regulations. The last survey was in 2012 and the center for justice statistic let the NSO to be the data collector and let the academic institution or scholars to be the processors in the pattern of the research funding project showing in the complete research study report under the crime statistic survey 2012 (Suvananont et al., 2012)

\subsubsection{The Problem of the Making Crime Statistic Survey Report}

The crime victimization survey mentioned above still has some error such as bringing the US questionnaire survey by not adjusting to the Thai context especially in the identity Theft. Also, there is the limitation of the data collecting from the data collecting officers that works only for the official time and not work at night and weekends. This makes no data providers working the same time as the data collecting officers causing the obtained data deviate from the truth as well as there is the limitation on the telephone installation in Thailand that does not cover all households causing the use of data collecting by phone which has been used in the US and United Kingdom cannot operate in Thailand. In addition, there is also the limitation of the data publication causing the bad outcome to the government sectors making the office of justice affairs cannot publish some of these data.

\subsection{The Way of Making the Rangsit Crime Survey Project}

The researcher received the respond opinions from the experts and found that the way of making the Rangsit Crime survey should be as follows:

1. The Rangsit crime survey project should use the 5 groups of the crime statistics from the Royal Thai Police to be the starting case of the data collecting. Although there are some problems in the case classification, the data from the Royal Thai Police which has the crime diversification making us to compare the difference of the arrested data and the victimization data.

2. This project can create in the form of the comparison research of the 5 groups of the crime statistic from the Royal Thai Police with the crime victimization survey of the office of justice affairs by using the budget less than doing by the Rangsit University.

3. The crime survey should be in the form of the cooperation among the related organization because the data collecting need to collect nationwide. If the Rangsit University collects the data by itself, it will spend a lot of budget and personnel more than 5 times of the office of justice affairs that use only 2 million Baht. Therefore, if the Rangsit University will be the project maker, it should cooperate with other academic institutions to save the budget and resources. However, the project by cooperating with other organizations may have some limitations. Also, if the Rangsit University wants to be the only data collecting, the experts suggested that it should let the department of probation collect the data and the university will be the processor.

4. The crime survey should implement in the form of the poll survey that will use less budget and resource as the office of justice affairs did. The poll should include "the fear of crime" survey in each area for every $3-4$ months and include "10 most serious crimes"

\section{Conclusion and Recommendation}

The study found that the crime statistic data collecting in Thailand still has the problems especially in the crime incident reports by the Royal Thai Police (5 groups of statistic crimes) that are not developed the collecting system to be standard since the starting of the program. The researcher suggested that the first thing to be done is to improve the data collecting system of the Royal Thai Police to be more modern and standardized. For the data of crime victimization by the office of justice affairs, the researcher found that it should adjust the survey form that adopt from the United States to be consistent with the Thai context especially in the crime recording type 4 "Identity Theft" which needs to change to "Fraud" instead.

For the Rangsit crime survey project, the pattern of the poll survey "the fear of crime" suggested by the experts which is the way to spend least budget and personnel has the most possibility to do by using the RSU crime survey and begins from the personnel of the College of Government and Public Governance by utilizing the 
normal budget or ad hoc budget from the university. Also, the researcher found that the poll making about the crime directly is less in number in Thailand. This crime poll survey will be useful to the citizen in the wide range and will create the outstanding points to the RSU poll about the crime. Thus, the researcher suggested that the Rangsit crime survey project should be in the form of poll survey.

\section{References}

Assumption University. (2012). ABAC Poll Research Center. Retrieved from http://www.abacpoll.au.edu BMRB. (2009). British Crime Survey 2009-10 Technical report. TNS-BMRB Report.

Boonyarit, S., et al. (2011). Basic statistics and research. Ayudthaya: Mahachulalongkornrajavidyalaya Press.

Buasonte, R. (2008). Qualitative research in education. Bangkok: Kum Samai Publishing.

Bureau of Justice Statistic. (2012). Criminal Victimization. Retrieved from http://www.bjs.gov/content/pub/press/ cv12pr.cfm

Central Information Technology Center, Royal Thai Police. (2013). Criminal Case Statistics Information. Retrieved from http://pitc.police.go.th/2013/

Central Information Technology Center. (2007). Crime Victimization Data-base Line in Bangkok 2005. Office of Justice Affairs, Ministry of Justice.

Central Information Technology Center. (2008). Crime Victimization Data-base Line in Nakhon Si Thammarat 2006. Office of Justice Affairs, Ministry of Justice.

Central Information Technology Center. (2009). Crime Victimization Data-base Line in Thailand 2007. Office of Justice Affairs, Ministry of Justice.

Central Information Technology Center. (2012). Thailand's Current Criminal Issues and Trends of Process of Criminal Justice Report. Office of Justice Affairs, Ministry of Justice.

Central Information Technology Center. (2013). Symbol. Retrieved from http://www.oja.go.th/new2011/Pages/ index.aspx

Corbetta, P. (2003). Social Research Theory, Methods and Techniques. London: SAGE Publications.

Department of Justice. (2004a). Crime in the United States in 2004. Retrieved from http://www2.fbi.gov/ucr/ cius_04/appendices/appendix_04.html

Department of Justice. (2004b). Uniform Crime Reporting Handbook. Retrieved from http://www.fbi.gov/ about-us/cjis/ucr/additional-ucr-publications/ucr_handbook.pdf

Home Office. (2011). User Guide to Home Office Crime Statistics: Last Updated October 2011." Retrieved from https://www.gov.uk/government/uploads/system/uploads/attachment_data/file/116226/user-guidecrime-statistics.pdf

Home Office. (2013). Home Office Counting Rules for Recorded Crime. Retrieved from https://www.gov.uk/ government/uploads/system/uploads/attachment_data/file/224119/count-general-july-2013.pdf

Jubb, V. (1998). Methods of Criminological Research. USA and Canada: Routledge.

Katikarn, K., \& Uaamnoey, J. (2007). Crime Victimization Survey in Bangkok. Office of Justice Affairs, Ministry of Justice.

Katikarn, K., \& Uaamnoey, J. (n. d.). A New Paradigm of Criminal Justice Data Base System Development: from Public Sector to Civil Sector. Retrieved from http://www.oja.go.th/new2011/document/Lists/ Download_1/Attachments/23/oja_symposium_5_G1_room1.pd, 2550.

Mcguire, M. (2012). Criminal Statistics and the Construction of Crime. In The Oxford Handbook of Criminology (5th ed.). Oxford: Oxford University Press. http://dx.doi.org/10.1093/he/9780199590278.003.0008

Newburn, T. (2007). Criminology. Devon: Willian

Office for National Statistics. (2012). Crime in England and Wales, Quaterly First Release to December 2011. Retrieved from http://www.ons.gov.uk/ons/dcp171778_263244.pdf

Phophueksanand, N. (2008). Research Methodology. Bangkok : Expernet.

Poll, N. (2012). History of Nida Poll. Retrieved from http://nidapoll.nida.ac.th/main/index.php/en/history

Public Opinion Survey "Nida Poll," Institute of Development Administration (NIDA). (2012). Youth or Criminal. Retrieved from http:// www.prd.go.th/ewt_dl_link.php?nid=29219 
Siegel, L. J. (2011). Criminology: The Core' (4th ed.). Belmont: Wadsworth.

Smith, A. (2006). Crime Statistics: An independent review. The Secretary of State for the Home Department.

Suan Dusit Poll. (2010). History of Suan Dusit Poll. Retrieved from http://dusitpoll.dusit.ac.th/pages/info/history. html

Suan Dusit Poll. (2013). Criminal Problem Solutions 2013 by Civil Sector. Retrieved from http://dusitpoll.dusit.ac.th/polldata/2556/25561357451539.pdf

Suwannanond, A., et al. (2013). Full Paper: The Information about Victims of Crime around the Country in Every Province Report (Under the Statistical Victimization Crime Survey. Office of Justice Affairs, Ministry of Justice.

\section{Copyrights}

Copyright for this article is retained by the author(s), with first publication rights granted to the journal.

This is an open-access article distributed under the terms and conditions of the Creative Commons Attribution license (http://creativecommons.org/licenses/by/3.0/). 